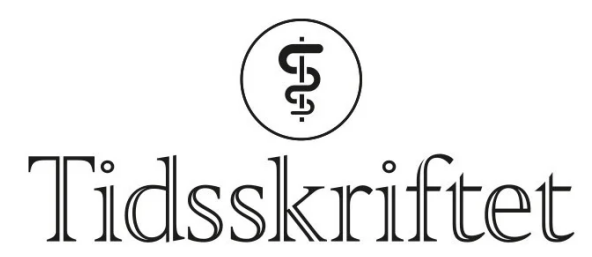

DEN NORSKE LEGEFORENING

\title{
Jak Jervell
}

\author{
MINNEORD
}

TORE JULSRUD BERG

JENS BOLLERSLEV

KÅRE I. BIRKELAND

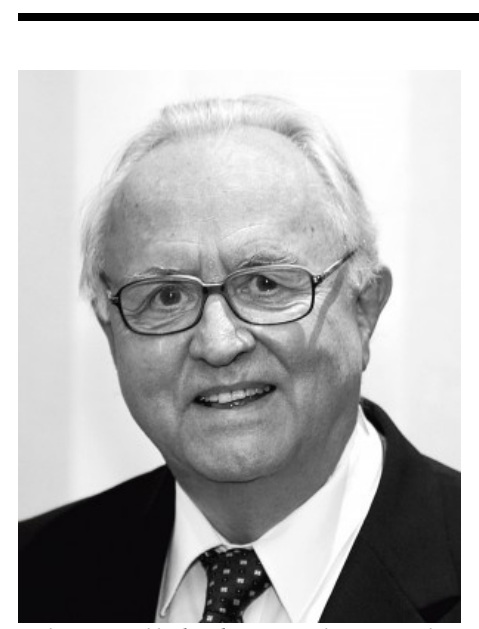

Jak Jervell døde 31. juli etter lengre tids sykdom, 88 år gammel. Han var spesiallege i endokrinologi og nefrologi på Medisinsk avdeling B, Rikshospitalet, senere Oslo universitetssykehus, og professor II ved Universitetet i Oslo. Jak var en karismatisk kunnskapsformidler av diabetes til medisinstudenter og helsepersonell og spilte en avgjørende rolle i utviklingen av pasientperspektivet i norsk diabetesomsorg. I en mannsalder var han lege ved Norsk Diabetikersenter og medisinsk medarbeider i Diabetesforbundet. Han initierte den internasjonale St. Vincent-deklarasjonen, en forløper for nasjonale og internasjonale handlingsplaner mot ikke-smittsomme sykdommer. Norge ble virkelig satt på det internasjonale «diabeteskartet» da han var president i den internasjonale diabetesføderasjonen (IDF) i perioden 1994-97.

Jak var en fantastisk blanding av en tradisjonell og en meget moderne lege, som la vekt på pasientens opplevelse og perspektiv. Han så det som et privilegium å arbeide med medmennesker (pasienter) med kronisk sykdom. Dette perspektivet var også sentralt i hans undervisning og veiledning av studenter. 
Et av hans hjertebarn var arbeidet med gravide med diabetes på Kvinneklinikken. Sammen med professor Narve Moe innførte han en moderne omsorg for gravide med diabetes. Disse tidlige tiltakene bedret betydelig prognosen for graviditeter hos diabetespasienter. I sine møter med pasienter med diabetes kunne han på sitt humoristiske spørsmål «Hvor mange av dere har fått barn med meg?», få mange hender i været som tegn på nitid oppfølging fra tidlig svangerskap til fødsel. I 2009 ble han utnevnt til ridder av 1. klasse av Den Kongelige Norske St. Olavs Orden.

Vi takker Jak for hans store betydning for diabetesomsorgen i Norge og internasjonalt. Jak var en inspirator på mange plan og spennende å arbeide sammen med. Våre tanker går til Eva, barn og barnebarn.

Publisert: 28. september 2020. Tidsskr Nor Legeforen. DOI: 10.4045/tidsskr.20.0641

(C) Tidsskrift for Den norske legeforening 2023. Lastet ned fra tidsskriftet.no 26. april 2023. 